\title{
Exploiting temporal-spatial patterns of informal settlements using GIS and remote sensing technique: a case study of Jimma city, Southwestern Ethiopia
}

\author{
Misgana Secho Abebe ${ }^{1}$, Kiros Tsegaye Derebew ${ }^{2}$ and Dessalegn Obsi Gemeda ${ }^{3 *}$
}

\begin{abstract}
Background: Temporal change detection of informal settlement was conducted using geographic information system and remote sensing in order to evaluate the land use land cover change (LULCC) in Jimma city, southwestern Ethiopia. We analyzed the LULCC since 1997 using Landsat imagery of 1997, and aerial photography of 2007 and 2017. Qualitative and quantitative data was also collected from city residents by using structured questionnaires focusing on peoples' perceptions to understand the pattern of informal settlements in the study area. Maximum likelihood supervised classification methods was employed to create the signature class of the five land cover classes: built up, vegetation, barren land, open land and agricultural land.

Results: The results indicated that the informal settlement has been increased in the peripheries from 29\% in 1997, 37\% in 2007 and $41 \%$ in 2017. This study focuses on the continued transformation of various land uses into informal settlements, causing encroachment on agricultural and open land particularly in the city periphery. The unprecedented population growth and unplanned development activities in urban areas results in urban agglomeration, which increase the price of land market for construction. This implies that rapid population growth, shortage of formal housing and unaffordable cost of formal housing for urban dwellers contributed to informal settlements.

Conclusions: Increasing urbanization and rapid population growth are often associated with the development of urban informal settlements. Informal settlements and urban informality are the common problems particularly in the periphery of Jimma city. These results can be used as a basis for informal settlement assessment in other cities in the country and beyond.
\end{abstract}

Keywords: Change detection analysis, Image classification, Unplanned settlement, Urbanization

\section{Introduction}

Informal settlement is a type of housing units construction that is made on a swath of land without legal claim from the municipality. It can also be referred to occupying land illegally and conduct unplanned housing constructions that does not comply with current planning and building regulations of a city. There are various synonyms term used for informal settlement, such as slum, squatter settlement,

\footnotetext{
*Correspondence: dessalegn.obsi@ju.edu.et; dasoobsi@gmail.com ${ }^{3}$ Department of Natural Resources Management, College of Agriculture and Veterinary Medicine, Jimma University, P. O. BOX 307, Jimma, Ethiopia Full list of author information is available at the end of the article
}

unplanned towns, and shanty town (Abunyewah et al. 2018). Khalifa (2011) defines the term slum as a residential area inhabited by extreme poor who have no land tenure and characterized by low quality or informal housing. Informal urban settlement has four common dimensions of informality such as lack of formal legal titles, irregular urban structure development, lack of essential public services, and the occurrence on public land (Inostroza 2017). This type of settlement is also considered as illegal settlement or squatter settlement; do not have legal right to occupy the land (Soyinka and Siu, 2018). It is uncontrolled mass urbanization (Lejano and Bianco 2018). Urban 
informal settlements are a self-building housing, substandard services, and low incomes of residents are often seen as problematic, because of poverty, irregularity and marginalization (Lombard 2014). Poor economic opportunities and an increasing shortage of affordable housing lead to informal settlements where the residents live without security of tenure and limited access to basic infrastructure (Penrose et al. 2010). This has adverse impacts on the life of informal settlers and urban development.

Rapid urbanization and population growth is of the key global development challenge for the twenty-first century (te Lintelo et al. 2018). Rapid population growth accompanied by economic activities causing subsequent land expansion for construction in developing countries (Guan et al. 2011). The world has experienced rapid urbanization and slum proliferation in twentieth and twenty-first century centuries (Mosammam et al. 2017). Informal settlements and urban informality are the common problems in third world countries (Nassar and Elsayed 2017). Developing countries are characterized by rapid, unstructured and unplanned development (Asmat and Zamzami 2012). The rapid population growth and unemployment in rural areas enhance the informal settlements in major cities of developing countries which resulted in a situation where more than half of the population resides in informal settlements (Payne 2005; Abunyewah et al. 2018).

Urban planning is a crucial tool to guide the growth of urban areas elsewhere. However, the planning practices and culture is not yet implemented on the ground. Even though, various measures have been undertaken to improve the conditions of slums in developing countries, their effectiveness is often questionable (Mweni 2012). As a result of population growth, the demand for affordable housing provisions is increasing. Because of financial constraints, the low economic class of the society forced to occupy urban land illegal. Urban informality is one of the key evidence of either housing deficit or unaffordable cost of formal housing (Roberts and Okanya 2018). Previous study conducted by Adam (2014) in the peri-urban areas of Bahir Dar in northern Ethiopia, indicates the procedural steps to make the illegal settlement to formal legal settlement- start with identifying a plot for sale and ends with the confirmation of traditional letter of agreement signed by transacting parties without legal ground to do so.

The predominance of spontaneous development, urban centers in Ethiopia has been posing a substantial need for planning intervention for urban center. Even though, Ethiopia is one of the least urbanized countries in Africa; its rate of urbanization has become quite dramatic recently (Esayas 2013). It has been observed that urbanization in Ethiopia is taking place at a much faster pace than population growth owing to decentralization (regional and municipal decentralization) in the post 1991 period
(Gulyani et al. 2001). Unplanned informal settlements have resulted in serious negative effects on the urban dwellers and their environment (Chadchan and Shakar 2012). Managing the growth and development of cities are very complex in nature since it has enormous challenges not only to utilities (Banda and Mwale 2018), but also it affects the surrounding environment, natural resources, health condition, social cohesion, and individual rights (Cohen 2006).

Several studies on the effects of informal settlement have been conducted. Majority of the study have focused on the effects of urban informality on the residents and local development. The findings of the previous studies (Abunyewah et al. 2018; Lejano and Bianco 2018; te Lintelo et al. 2018; Guan et al. 2011; Payne 2005) concludes that rapid urbanization, population boom, the level of economic status, and unplanned development activities are some of the major factors for the occurrence of informal urban settlements. The urban informality is common and serious problems in developing countries. However, the temporal-spatial pattern of informal settlement has not been carefully studied. Therefore, this paper aims at filling this critical knowledge gap through exploiting the temporal-spatial patterns of informal settlements in a fast growing Jimma city. This study will enhance public understanding towards the effects of informal settlements, which can contribute for developing effective planning and management strategies. Therefore, the aim of this study is to assess the temporal-spatial pattern of Jimma city informal settlement and its driving forces.

\section{Data and methods}

\section{Description of the study area}

Jimma city Administration is one of the oldest and historic cities in Ethiopia. It is in Oromia National Regional State, in Jimma zone (Fig. 1), located $352 \mathrm{kms}$ to Southwest of the Ethiopian capital, Addis Ababa. Geographically, the city is located at $7^{\circ} 40^{\prime} 24.47^{\prime \prime} \mathrm{N}$ latitude and $36^{\circ}$ $5^{\prime} 4.95^{\prime \prime}$ E longitude. Jimma city (the capital of Jimma Zone) is the most important city in Southwestern Ethiopia and the study area has been chosen because of the fast rate of urbanization and informal settlement and little study were made on it. The city has a total population of 195,443, of whom 97,629 are men and 97,814 women with an area of $100.2 \mathrm{~km}^{2}$ [Central Statistical Agency of Ethiopia], Central Statistical Agency of Ethiopia 2007).

As indicated in Table 1, a total of 34, 438 informal household numbers were identified, though participatory inventory of Jimma city administration land development and management. These informal households acquired land illicitly and built on privately owned agricultural land without planning laws and regulations. The informal settlements are living without sufficient infrastructure and services and they are not able to request the government for service delivery since they know themselves as illegal settlers. 


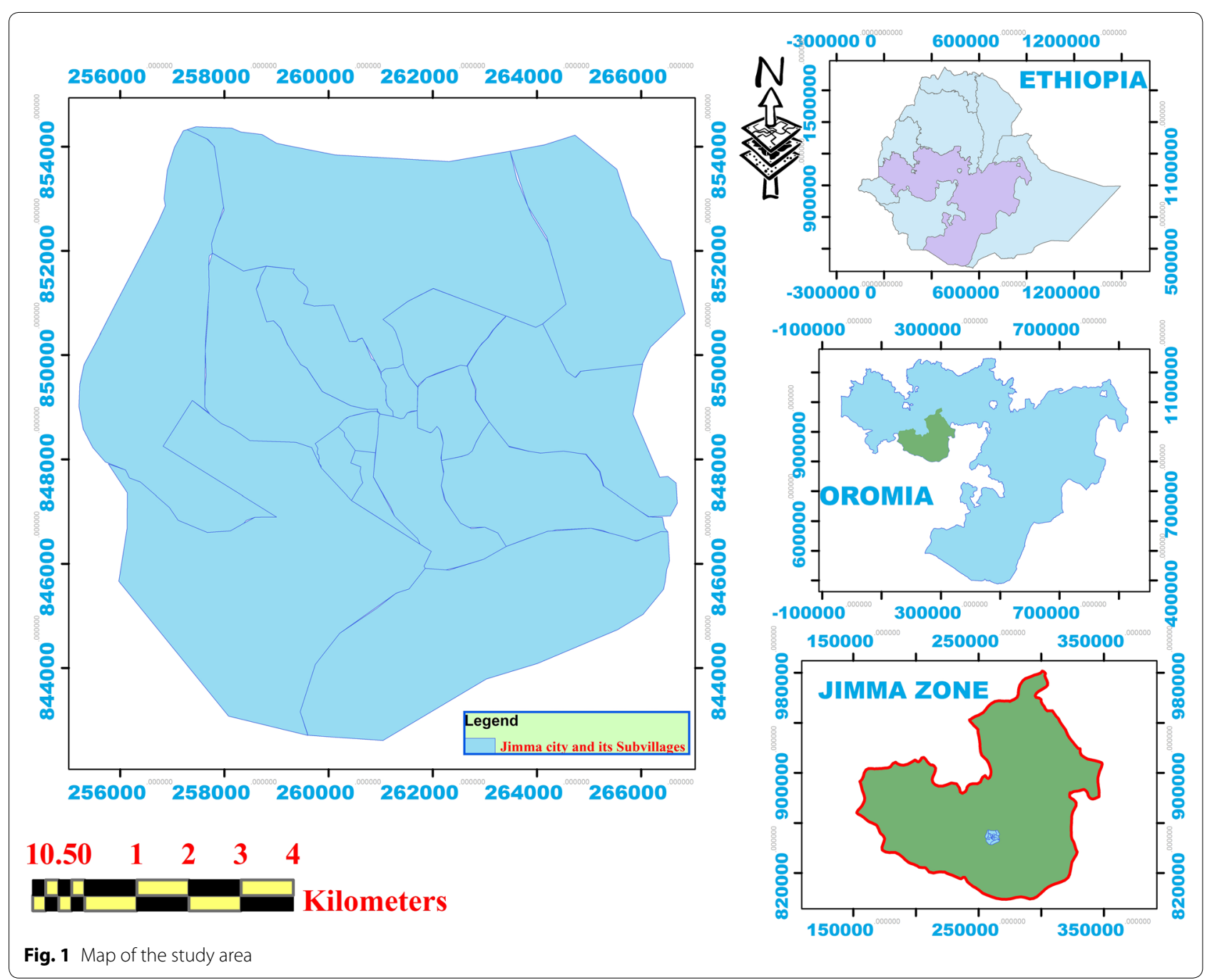

\section{Research methods and design}

This study used GIS and remote sensing software's like ArcGIS 10.2 and ERDAS imagine 2010 for analyzing the extent of informal settlements in Jimma city. Besides, GIS and remote sensing techniques, household questionnaire survey, on-site observation, and focused group discussions (FGDs) were used for qualitative information about the informal settlements. This research was performed following the underlying flowchart (Fig. 2).

\section{The sample size and sampling techniques}

Jimma city is one of the biggest cities in the southwestern part of Ethiopia with 17 villages. To select sample villages in the study area, preliminary field survey as well as FGDs was done with the stakeholders. Based on the information we gained through preliminary survey and FGDs, informal settlements are common across the city with high prevalence in six villages, namely Jiren, Bore,
Ifa Bula, Kofe, Saxo Samaroo and Ginjo (Table 1). The six villages are found around the peripheries of Jimma city.

For socioeconomic data collection, because of resource scarcity to carry out a large scale survey and homogeneity of the population, we used the multi-stage sampling techniques following established procedure (Okoffo et al. 2016) for sample size determination. The multi-stage sampling has three stages. In the first stage, the six villages, namely Jiren, Bore, Ifa Bula, Kofe, Saxo Samaroo, and Ginjo were purposively selected from the existing 17 villages based on the severity of the informal settlements. In the second stage, exclusion criterion was developed to focus on the number of household unit, who resides in the study area for more than 20 years for household questionnaire surveys. In the final stage, 21 housing hold units were randomly selected from each of the six selected villages. Therefore, a total of 126 household units were randomly selected from the six villages for the study. 
Table 1 Number of registered and informal household in 2018

\begin{tabular}{llccc}
\hline No. & Village name & $\begin{array}{c}\text { Household } \\
\text { in 2018 }\end{array}$ & $\begin{array}{l}\text { Registered } \\
\text { households }\end{array}$ & Informal \\
\hline 1 & Ginjo Guduru & 2298 & 1091 & 1207 \\
2 & Awetu Mendara & 1185 & 405 & 780 \\
3 & Hermata & 662 & 214 & 448 \\
4 & Mantina & 964 & 440 & 524 \\
5 & Mendera Kochi & 5170 & 1591 & 3579 \\
6 & Saxo Semaro & 4293 & 620 & 3673 \\
7 & Ginjo & 5795 & 1430 & 4365 \\
8 & Bacho Bore & 9000 & 1736 & 7264 \\
9 & Bosa Addis Ketama & 2275 & 635 & 1640 \\
10 & Bosa kitto & 4100 & 1728 & 2372 \\
11 & Hermata Merkato & 1674 & 416 & 1258 \\
12 & Hermata Mantina & 1518 & 335 & 1183 \\
13 & Jiren & 2500 & 0 & 2500 \\
14 & Ifa Bula & 1567 & 0 & 1567 \\
15 & Kofe & 579 & 0 & 579 \\
16 & Bore & 1211 & 0 & 1211 \\
17 & Hora Gibe & 335 & 0 & 335 \\
& Total & 45,126 & 10,641 & 34,438 \\
\hline
\end{tabular}

Source: Jimma city administration land development and management, 2018

\section{Data source and instruments}

Data for this article is drawn from a combination of primary and secondary data. Primary data were collected through household surveys, FGDs, in-depth interviews and site observation, while secondary data was obtained from Jimma city Municipality, and CSA of Ethiopia. The Landsat TM 1997 with $30 \mathrm{~m} \times 30 \mathrm{~m}$ resolution and Aerial Photography (2007 and 2017 with $15 \mathrm{~m} \times 15 \mathrm{~m}$ resolution) were used to detect the LULCC following (Poyil and Misra 2015; Shaw and Das 2018). Characteristics of the satellite data used in this study are summarized in Table 2.

\section{Data analysis}

Temporal and spatial variations of informal settlements were analyzed for the Jimma city to determine the extent of unplanned urban growth over the study period. Percentages of each land use class, including built up area, vegetation, barren land, open land and agricultural land for 1997, 2007, and 2017 were analyzed for changes in LULC and its implications on urban expansions to the periphery.

To calculate the change in percentage (\%), the initial and final LULC area coverage was compared following Garai and Narayana (2018) as indicated in Eq. 1.

$$
\begin{aligned}
& \text { Change percentage } \\
& =\frac{(\text { present LULC area }- \text { previous LULC area })}{2 ! \text { previous LULC area }} \times 100
\end{aligned}
$$

Maximum likelihood supervised image classification (Chima et al. 2017) was carried out by using ArcGIS10.2 software and ERDAS 2010 software to produce LULC maps of 1997, 2007 and 2017. Accordingly, five LULC classes were generated which included: built up, vegetation, barren land, open land and agricultural land. Remote sensing images change detection approaches (Yuan et al. 2005) and the postclassification change detection approach (Hung and Wu 2005; Haque and Basak 2017) was used to assess the change results from 1997 to 2017. Classified image pairs of two different time phases are compared using cross-tabulation to assess qualitative and quantitative aspects of the change for the study period. A change matrix is generated following Weng (2001) to determine the overall LULCC gains and losses in each land use category between 1997 and 2017 are then compiled. Finally, the change detection of informal settlement map of the study area was produced. Socioeconomic data obtained from field survey through questionnaires, field observation and interview were analyzed.

\section{Results and discussions}

\section{Jimma city land use land covers change (1997-2017)}

This study used past and recent satellite data to evaluate the land use change over the study period. For this purpose, five LULC were produced. These included; built up, vegetation, barren land, open land and agricultural land. As indicated in Table 3, the highest LULC in 1997 was open land (37.86\%) followed by agricultural land $(21.48 \%)$ and barren land (16.50\%), while vegetation (13.92\%) and built up area (10.24\%) is the least LULC classes in 1997. The analysis of LULCC revealed that the built-up area was 1081.9 ha $(10.24 \%)$ of the study area in 1997 was increased to about 1160.3 ha in 2007. The agricultural land is decreased from 2269.5 ha in 1997 to 2235 ha in 2007. In contrary to vegetation, barren land, and built up areas, the open land and agricultural land was decreased by the year 2007 . There has been a transformation from open land and agricultural lands to built-up area caused by rapid urbanization and slum proliferation (Mosammam et al. 2017; Esayas 2013; Guan et al. 2011).

In 2017, the LULC classification of Jimma city indicates that the highest proportion is vegetation land (30.65\%), followed by barren land (21.23\%) and open land $(17.66 \%)$. The vegetation class shows a radical increasing in the study area because of the protection of the green area as well as the culture of the community in planting edible fruit trees and others. The increment of vegetation LULC class is a direct reflection 


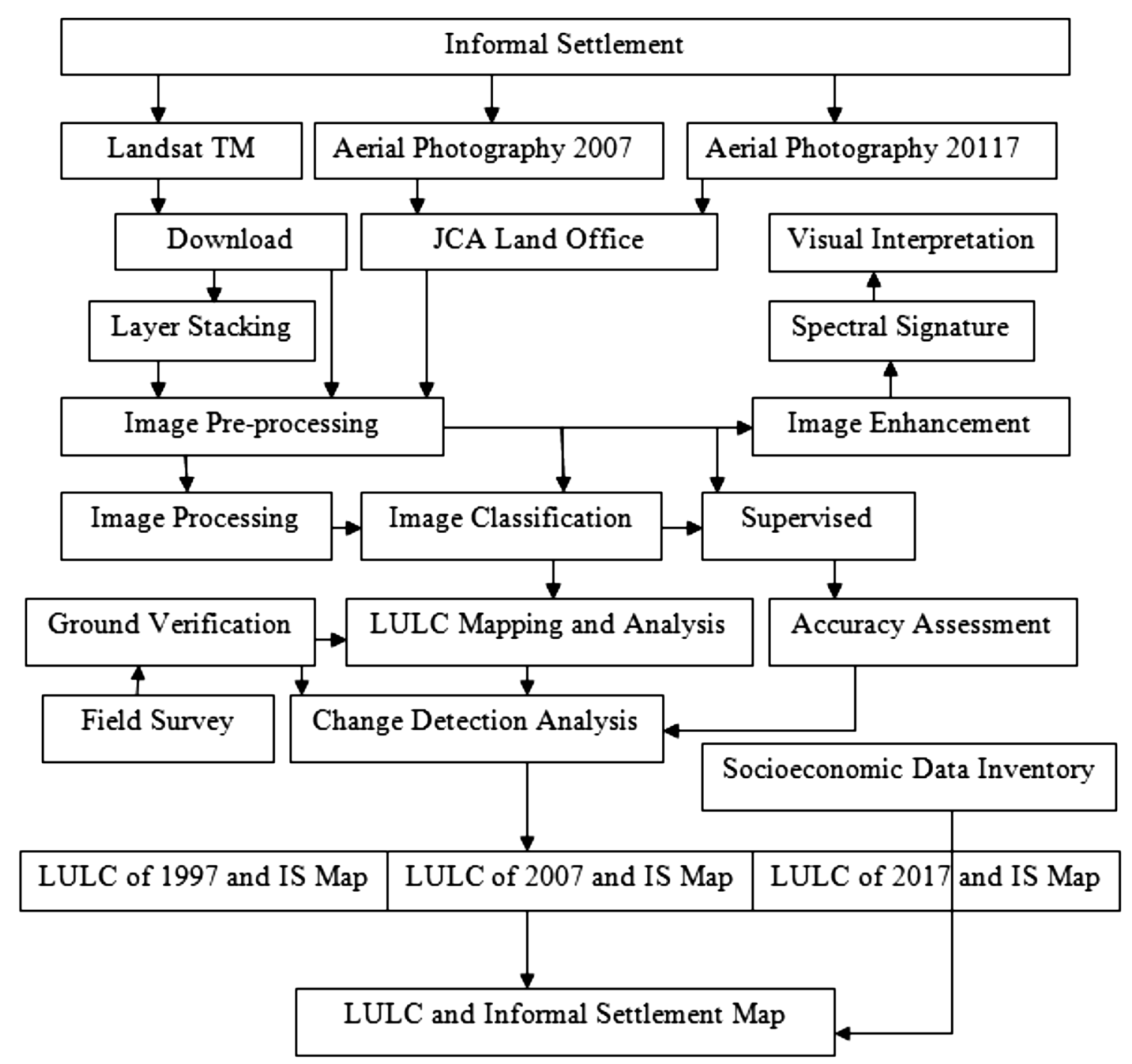

Fig. 2 Research Methodological flowchart

Table 2 Imagery data used for the study

\begin{tabular}{lllll}
\hline S. no & Sensor & Acquisition year & Source & $\begin{array}{l}\text { Resolution } \\
(\mathbf{m})\end{array}$ \\
\hline 1 & Landsat (MSS) & 1997 & USGS & 30 \\
2 & Aerial photograph & 2007 & JCA & 15 \\
3 & Aerial photograph & 2017 & JCA & 15 \\
\hline
\end{tabular}

of the government policy of millennium afforestation programme to enhance the forest coverage of the country. The built-up land cover class shows a remarkable increased between 2007 and 2017, which has been increased in size from 1160.3 ha in 2007 to 1402.2 ha in 2017, while the agricultural land was experiencing an extremely decreased from 2235 ha (21.16\%) in 2007 to 1814 ha $(17.17 \%)$ in 2017 . The increment of built up area over the study period was associated with rapid population growth, migration of people from neighboring city and unable to compete the land lease price. These results are consistent with (te Lintelo et al. 2018 and Mosammam et al. 2017) who reported that the rapid urban population is a key challenge of the twentyfirst century. Three land cover classes namely built up, vegetation and barren land shows an increasing trend throughout the study periods (Fig. 3).

The built-up area shows increasing trend from 1997 to 2017 covering an area of 1081.9 ha $(10.24 \%)$ in the year 1997 and 1160.3 ha (10.98\%) and 10 years later this land cover class increased to 1402.2 ha $(13.27 \%)$ in 
Table 3 Summary of Jimma city land covers matrix statistics for 1997, 2007, and 2017

\begin{tabular}{|c|c|c|c|c|c|c|c|c|c|c|c|c|}
\hline \multirow[t]{2}{*}{ Land cover } & \multicolumn{2}{|l|}{1997} & \multicolumn{2}{|l|}{2007} & \multicolumn{2}{|l|}{2017} & \multicolumn{2}{|c|}{ 1997-2007 } & \multicolumn{2}{|c|}{$2007-2017$} & \multicolumn{2}{|c|}{$\begin{array}{l}\text { Land cover change } \\
\text { in ha (1997-2017) }\end{array}$} \\
\hline & ha & $\%$ & ha & $\%$ & ha & $\%$ & ha & $\%$ & ha & $\%$ & ha & $\%$ \\
\hline Built up & 1081.9 & 10.24 & 1160.3 & 10.98 & 1402.2 & 13.27 & 78.4 & 6.76 & 241.9 & 17.25 & 320.3 & 22.84 \\
\hline Vegetation & 1470 & 13.92 & 1551 & 14.68 & 3238 & 30.65 & 81 & 5.22 & 1687 & 52.10 & 1768 & 54.60 \\
\hline Barren land & 1743.1 & 16.50 & 1871 & 17.71 & 2243.1 & 21.23 & 127.9 & 6.84 & 372.1 & 16.59 & 500 & 22.29 \\
\hline Open land & 3998.8 & 37.86 & 3746 & 35.46 & 1866 & 17.66 & -252.8 & -6.75 & -1880 & -100.75 & -2132.8 & -53.33 \\
\hline Agricultural land & 2269.5 & 21.48 & 2235 & 21.16 & 1814 & 17.17 & -1.54 & -1.54 & -421 & -23.21 & -455.5 & -25.11 \\
\hline Total & $10,563.3$ & 100 & $10,563.3$ & 100 & $10,563.3$ & 100 & & & & & & \\
\hline
\end{tabular}

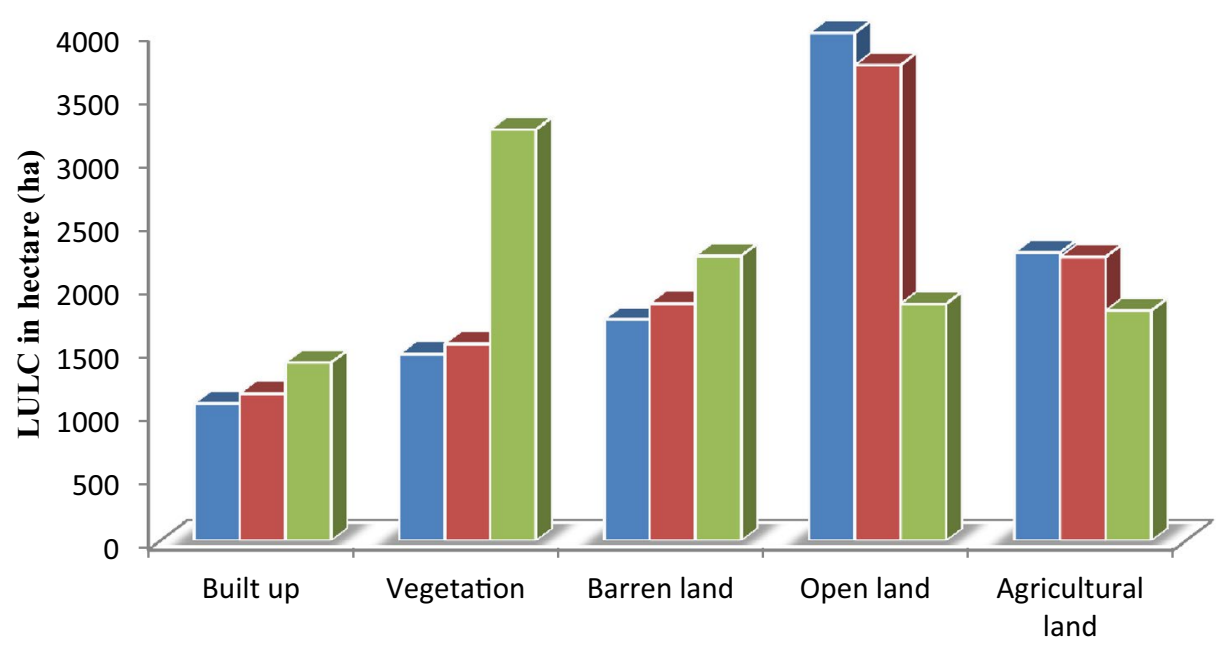

Fig. 3 Jimma city LULC in 1997, 2007, and 2017

the year 2017. Studies including Asmat and Zamzami (2012) and Esayas (2013) also found comparable results with increased built-up area due to rapid, unstructured and unplanned development. The increasing trends are also observed in vegetation and barren land. However, the open land that occupies over 3998 ha (37.86\%) in 1997, decreased to 1886 ha (17.66\%) in 2017. The declining trend of the open land is due to increasing land requirements for house construction, which is arising from rapid population growth and uncontrolled response by the government (Lejano and Bianco 2018), which enhances the problem of informal house constructions. These findings are supported by Roberts and Okanya (2018), who reported urban informality, is the outcome of either housing deficit or unaffordable cost of formal house rent.

It is observed that the vegetation cover has increased from 1470 (13.92\%) in the year 1997 to 1551 (14.68\%) in the year 2007, and the increasing trend of vegetation coverage is continued throughout the study period, and increased to $3238(30.65 \%)$ by the year 2017 . The barren land of the study area also shows an increasing trend from 1997 to 2017 covering a total area of 1743.1 (16.50\%) in the year 1997 and 2243.1 (21.23\%) in 2017. Maximum positive change is observed in vegetation land cover, especially during 2007-2017, whereas maximum negative change is observed in open land during the year 2007-2017.

Land use land cover matrix of Jimma city administration To acquire changes of the five land cover classes over the study period (1997-2017), the change matrix was conducted through cross tabulation to investigate the trend, net change, and percent change between 1997 and 2007, 2007 and 2017, and for the overall study period 1997 and 2017.

The study reveals that the built-up is expanding in the periphery of the city, particularly in southwestern and the eastern part of the city (Fig. 4). Our study reports that the built-up land increased, which is in consistent 


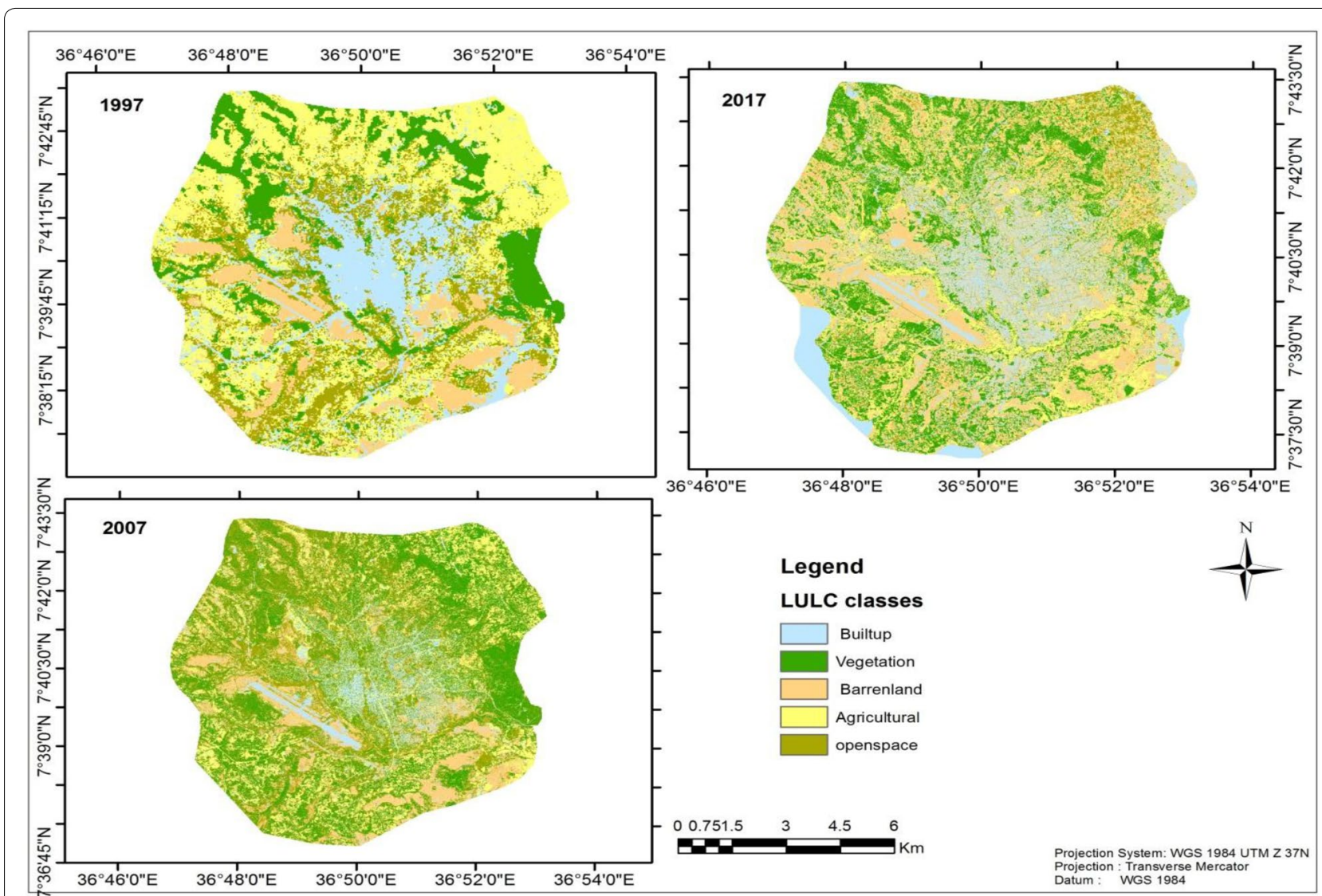

Fig. 4 The land use/land cover changes in Jimma city area during the study period from 1997 to 2017

with previous studies (Esayas, 2013; te Lintelo et al. 2018). We found that the built-up area increased more rapidly in the periphery of the city and while it remain stable near to the main road. Such increase in the periphery of the city is mainly due to rapid population of the city. As reported by Guan et al. (2011), rapid population growth and economic development has led to expansions of built up areas.

\section{Change detection of informal settlement in 1997}

Findings presented in Table 4 indicate that the proportion of non-built is $71 \%$, while the built up accounts about 29\%. This finding agrees with Nassar and Elsayed
(2017), the informal settlement and urban informality is a serious problem in third world countries. Information we collected though focused group discussions shows, there is a deficit of house for rent as well as the increment of house rent from private sectors contributes for the occurance of informal settlements in the perphery of the city. The informal settlers are social excluded and psychological threatened since they are illegal; not able to request public service facilities from the government.

In 2007, the built up kept the pace of growth and gained additional 666 ha $(8 \%)$ increased from 2315.88 ha (29\%) in 1997 to 2982 ha (37\%) in 2017. Unpredictable, built-up (informal settlement) increased from 29\% in 1997 to $37 \%$

Table 4 Change detection of informal settlement for the year 1997, 2007, and 2017

\begin{tabular}{|c|c|c|c|c|c|c|c|}
\hline \multirow[t]{2}{*}{ LULC Type } & \multicolumn{2}{|l|}{1997} & \multicolumn{2}{|l|}{2007} & \multicolumn{2}{|l|}{2017} & \multirow{2}{*}{$\begin{array}{l}\text { Change } \\
\text { in ha (from } \\
\text { 1997-2017) }\end{array}$} \\
\hline & ha & $\%$ & ha & $\%$ & ha & $\%$ & \\
\hline Built-up & 2315.88 & 29 & 2982 & 37 & 3316 & 41 & 1000.12 \\
\hline No built & 5766.12 & 71 & 5106 & 63 & 4772 & 59 & -994.12 \\
\hline Total & 8082.27 & 100 & 8082 & 100 & 8082 & 100 & \\
\hline
\end{tabular}


in 2007, while, the no built area slightly decreased from $5766.39(71 \%)$ in 1997 to $5106(63 \%)$ in 2007. From the total 8082.27 ha, about 2982 ha (37\%) built area belongs to informal settlers.

It is evident that the informal settlement in the study area is highly increasing. The change detection analysis shows that there is a rapid increase in the built up areas from 2982 ha (37\%) in 2007 to 3316 ha (41\%) in 2017. Of the total land area for the six sub-city account about 8088 ha, the non built area is 4772 ha $(59 \%)$.

Figure 5 shows the comparison of informal settlements over the study period (1997-2017). The black colour indicates the informal settlements, which is highly concentrated in the periphery of Jimma city. In 1997, the informal settlements is not much known. However, from 2007 onwards the informal settlemets is increasing in the study area which is associated with human population growth (Abunyewah et al. 2018), rising of land prices, and rural to urban migration accelerated the problems of informal settlements in the periphery of Jimma city. The population trend of Jimma city contributes for informal settlements, the city administration faces service provision challenges to the informal settlers: the absence of a proper drainage system, dwellers' along the peripheries lacks the road networks and sustainable electricity are limited for dwellers along the peripheries. The informal settlement has negative effects on urban dwellers and their environment (Chadchan and Shakar 2012; Cohen 2006). Above all, the unprecedented population growth coupled with unplanned development activities has led to urban agglomeration, which lacks infrastructure facilities.

Major driving factors for informal settlement in Jimma city Data collected from the household survey through questionnaire, and interview revealed that informal settlements were the product of the existing land lease

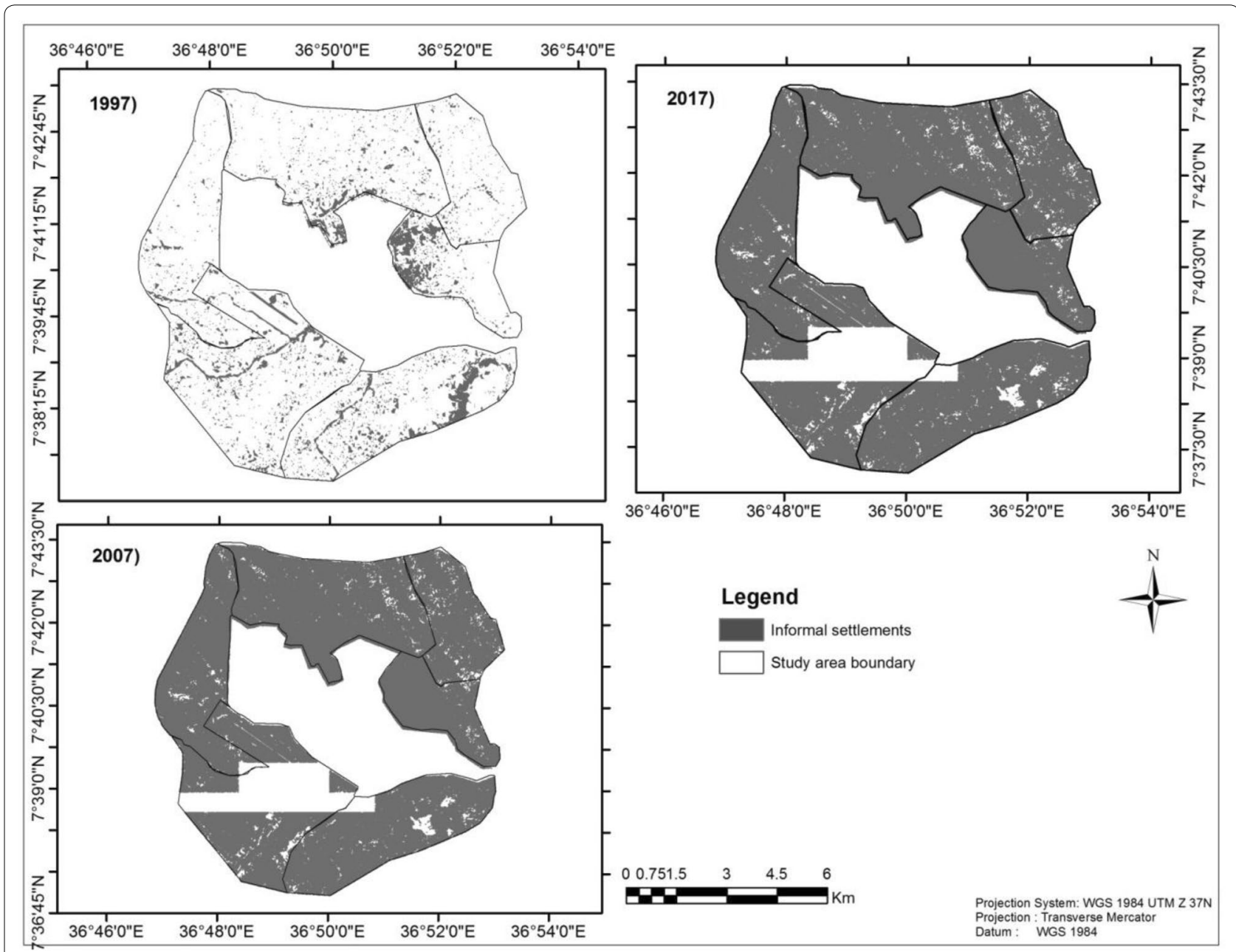

Fig. 5 Informal Settlement Map of Jimma city in 1997, 2007, and 2017 


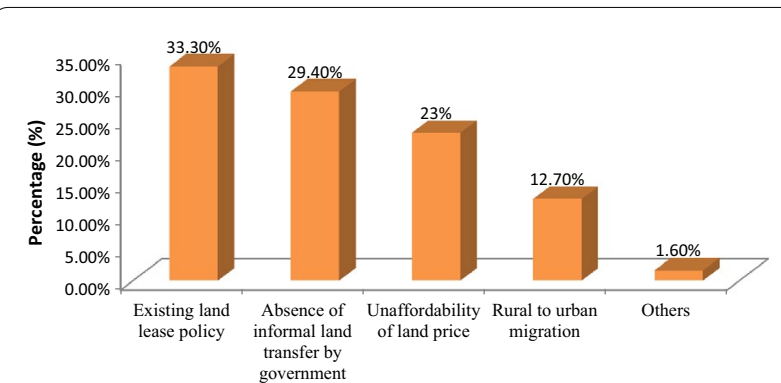

Fig. 6 The driving factors for informal settlement (Source: Field Survey 2018)

policy (33.3\%) and absence of formal land transfer by a government (29.4\%) followed by expensive land price (23\%) and migration from rural areas only contributes for about $12.7 \%$ (Fig. 6).

The household survey results indicated that majority of respondents $(86 \%)$ believe that the land lease proclamation highly contributed towards informal settlement; whereas, $14 \%$ perceived that the lease proclamation has no impact on the expansion of informal settlement. As the interviews and data from land development and management office indicates the informal settlement is greatly increased after the lease proclamation of $721 / 2004$. This land lease proclamations aimed to keep land in the ownership of the state through transferring all urban land holdings into the lease system to improve the development of urban infrastructure. Land lease policy increase urban land price since every interested individual will compute to win by increasing the land lease price per meter square. Since the leasing system competing by cost the poor is unable to compete with those who have enough resources and unable to win the chance to involve into the informal settlement. The increment of this land price in Jimma city is directly associated with rapid urbanization and population growth (te Lintelo et al. 2018), which enhances the demand of land market for house constructions.

Data obtained from expert's interview shows that unemployment and unable to pay the land lease price immensely contributed for the increasing number of informal settlements. The respondents also confirmed that the city has land use related problems such as insecurity of tenure, large land stocking by individuals and unfair compensations for land owners (who occupied the land before urban expansions). Information obtained from focused group discussions indicates that the migration of the youth from rural areas to the city for job search increased the number of people living in informal settlements throughout the city.

The rapid increment of human population, changing lifestyles, and high urbanization will continue to widen the gap between the demand for housing and available supply around Jimma city, which contributes for informal settlement. The results from socioeconomic data shows that various factors such as; informality, lack of awareness, weak land policy enforcement, loopholes (ambiguity) of law, corruption, and other factors like shortage labour force and resources are some of the challenges Jimma city land administration. These all problems make the management of cities more complex in nature as described by Banda and Mwale (2018). As indicated in Fig. 7, informality and lack of awareness accounts about $66 \%$ are the dominant challenges of city land administration.

Informality has a negative impact not only on the government, but also the informal settlers in various dimensional (Fig. 8). Data obtained from household survey indicate that, the informal settlement affects the economic advantage of the owner (31.7\%), insecurity of the ownership (31\%), affects the municipal revenue (27\%), and illegal use of scarce land resource (10.3\%).

\section{Conclusions}

Increasing urbanization and rapid population growth has exaggerated the problem of informal settlements. An informal settlement in the urban periphery is a common and serious problem in Ethiopia particularly in Jimma city. Due to informal settlement, the scarce land resource is misused and the government lost revenue from the illegal dwellers. The government is facing great challenges from the emerging informal settlements as they accommodate a substantial proportion of the urban population who lives in substandard living conditions. Understanding the characteristics, extent and pattern of land use change are an important supporting tool for decision making processes. This paper was analyzed the LULCC to identify the extent of informal settlements using GIS and remote sensing technologies over the time period of 20 years. Combing data from socioeconomic survey and multi-temporal remote sensing images reveals that there

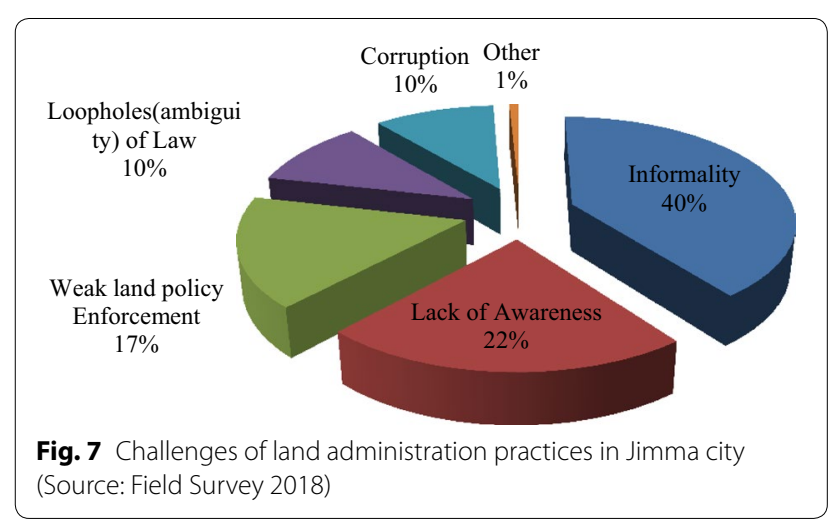




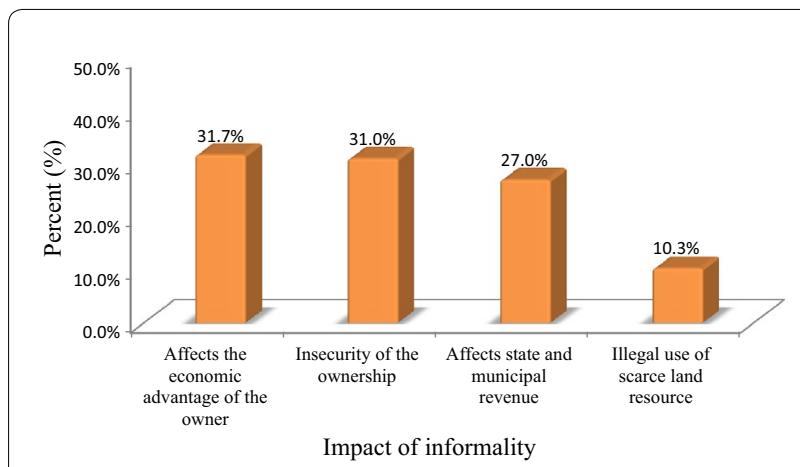

Fig. 8 Impacts of informality from informal settler's point of view (Source: Field Survey 2018)

is a fast increase of informal settlements outside of city municipality boundaries. The LULCC analysis results indicated that the built-up area has shows an increasing trend over the last two decades, i.e., the built-up land use type is the only land use class that shows increasing trends in the study area, while agricultural land use was affected largely due to conversion into built-up areas. The rapid increasing of built-up areas and a fast declining of agricultural lands leads to dramatic changes in LULC classes in the study area.

\section{Abbreviations}

CSA: Central Statistical Agency of Ethiopia; FGDs: focused group discussions; GIS: geographic information science; Ha: hectare; IS: informal settlements; JCA: Jimma city Administration; LULC: land use land cover; LULUC: land use land cover change.

\section{Authors' contributions}

MSA has conceived of the study. He designed the study, carried out the field work, satellite image analysis, and document analysis. KTD has participated in research design and coordination as well as manuscript editorial works and DOG have participated in literature work, manuscript draft and editorial. All authors read and approved the final manuscript.

\section{Author details}

1 Jimma City Land Management and Development Office, Jimma, Ethiopia. ${ }^{2}$ Department of Geography and Environmental Studies, College of Social Sciences and Humanities, Jimma University, Jimma, Ethiopia. ${ }^{3}$ Department of Natural Resources Management, College of Agriculture and Veterinary Medicine, Jimma University, P. O. BOX 307, Jimma, Ethiopia.

\section{Acknowledgements}

The authors would like to thank Jimma University College of Social Sciences and Humanities, Department of Geography and Environmental Studies for providing research fund and Jimma University College of Agriculture and Veterinary Medicine, Department of Natural Resources Management for the existing facilities to download necessary supporting materials particularly scientific documents. We like to acknowledge Dessalegn Debelo Serba for language editorial works. We also like to acknowledge Mr. Merga Wirtu Dingo for connecting us with Dessalegn Debelo Serba for editorial activities.

\section{Competing interests}

The authors declare that they have no competing interests.

Availability of the data and materials

The data is included in the manuscript.

\section{Consent for publication}

We have agreed to submit for Environmental Systems Research and approved the manuscript for submission.

\section{Ethics approval and consent to participate}

Not applicable since this research did not involved human subject.

\section{Funding}

This study was conducted with financial support of Jimma University, College of Social Sciences and Humanities.

\section{Publisher's Note}

Springer Nature remains neutral with regard to jurisdictional claims in published maps and institutional affiliations.

Received: 26 October 2018 Accepted: 12 February 2019

Published online: 25 February 2019

\section{References}

Abunyewah M, Gajendran T, Maund K (2018) Profiling informal settlements for disaster risks. In: 7th International conference on building resilience; using scientific knowledge to inform policy and practice in disaster risk reduction, ICBR2017, 27-29 November 2017, Bangkok, Thailand. Procedia Eng 212:238-245. https://doi.org/10.1016/j.proeng.2018.01.031

Adam AG (2014) Informal settlements in the peri-urban areas of Bahir Dar, Ethiopia: an institutional analysis. Habitat Int 43:90-97. https://doi. org/10.1016/j.habitatint.2014.01.014

Asmat A, Zamzami SZ (2012) Automated house detection and delineation using optical remote sensing technology for informal human settlement. Procedia Soc Behav Sci 36:650-658. https://doi.org/10.1016/j.sbspr 0.2012 .03 .071

Banda EM, Mwale FD (2018) Utility performance in supplying water to informal settlements: a case study from Malawi. Util Pol 55:151-157

Central Statistical Agency of Ethiopia (2007) Ethiopia-population and housing census. 2007. http://microdata.worldbank.org/index.php/catalog/2747. Accessed 23 Oct 2018

Chadchan J, Shakar R (2012) An analysis of urban growth trends in the posteconomic reforms period in India. Int J Sustain Built Environ 1:36-49. https://doi.org/10.1016/j.ijsbe.2012.05.001

Chima Cl, Trodd N, Blackett M (2017) Assessment of Nigeriasat-1 satellite data for urban land use/land cover analysis using object-based image analysis in Abuja. Geocarto Int, Nigeria. https://doi.org/10.1080/10106 049.2017 .1316778

Cohen B (2006) Urbanization in developing countries: current trends, future projections, and key challenges for sustainability. Technol Soc 28:63-80. https://doi.org/10.1016/j.techsoc.2005.10.005

Esayas E (2013) Urban planning and land management challenges in emerging towns of Ethiopia: the case of Arba Minch. J Urban Environ Eng 7(2):340-348

Garai D, Narayana AC (2018) Land use/land cover changes in the mining area of Godavari coal fields of southern India. Egypt J Rem Sens Space Sci 21(3):375-381

Guan DJ, Li HF, Inohae T, Su WC, Nagaie T, Hokao K (2011) Modeling urban land use change by the integration of cellular automaton and Markov model. Ecol Model 222:3761-3772. https://doi.org/10.1016/j.ecolm odel.2011.09.009

Gulyani S, De Groot D, Yitbarek T, Meheret A, Connors G (2001) Municipal decentralization in Ethiopia. Rapid Assessment, Draft Report, Addis Ababa

Haque MI, Basak R (2017) Land cover change detection using GIS and remote sensing techniques: a spatio-temporal study on Tanguar Haor, Sunamganj, Bangladesh. Egypt J Rem Sens Space Sci 20:251-263. https://doi. org/10.1016/j.ejrs.2016.12.003

Hung M, Wu Y (2005) Mapping and visualizing the Great Salt Lake landscape dynamics using multi-temporal satellite images, 1972-1996. Int J Remote Sens 26:1815-1834. https://doi.org/10.1080/0143116042000298324

Inostroza L (2017) Informal urban development in Latin American urban peripheries. Spatial assessment in Bogota, Lima and Santiago de Chile. 
Landsc Urban Plann 165:267-279. https://doi.org/10.1016/j.landurbpla n.2016.03.021

Khalifa MA (2011) Redefining slums in Egypt: unplanned versus unsafe areas. Habitat Int 35:40-49

Lejano RP, Bianco CD (2018) The logic of informality: pattern and process in a Sao Paulo favela. Geoforum 91:195-205. https://doi.org/10.1016/j.geofo rum.2018.03.005

Lombard M (2014) Constructing ordinary places: place-making in urban informal settlements in Mexico. Progr Plann 94:1-53. https://doi.org/10.1016/j. progress.2013.05.003

Mosammam HM, Nia JT, Khani H, Teymouri A, Kazemi M (2017) Monitoring land use change and measuring urban sprawl based on its spatial forms. The case of Qom city. Egypt J Rem Sens Space Sci 20:103-116. https:// doi.org/10.1016/j.ejrs.2016.08.002

Mweni ME (2012) Change detection of informal settlements using remote sensing and geographic information systems: Case of Kawangware, Nairobi (1990-2010)

Nassar DM, Elsayed HG (2017) From informal settlements to sustainable communities. Alexandria Eng J 57(4):2367-2376

Okoffo ED, Mensah M, Fosu-Mensah BY (2016) Pesticides exposure and the use of personal protective equipment bu cocoa farmers in Ghana. Environ Syst Res 5:17. https://doi.org/10.1186/s40068-016-0068-z

Payne G (2005) Getting ahead of the game: a twin-track approach to improving existing slums and reducing the need for future slums. Environ Urban 17(1):135-146

Penrose K, de Castro MC, Werema J, Ryan ET (2010) Informal urban settlements and Cholera risk in Dar es Salaam, Tanzania. PLoS Negl Trop Dis 4(3):e631. https://doi.org/10.1371/journal.pntd.0000631
Poyil R, Misra AK (2015) Urban agglomeration impact analysis using remote sensing and gis techniques in Malegaon city, India. Int J Sustain Built Environ 4(1):136-144. https://doi.org/10.1016/j.ijsbe.2015.02.006

Roberts RE, Okanya O (2018) Measuring the socioeconomic impact of forced evictions and illegal demolition: a comparative study between displaced and existing informal settlements. Soc Sci J 1:1. https://doi.org/10.1016/j. soscij.2018.12.003

Shaw R, Das A (2018) Identifying per-urban growth in small and medium towns using gis and remote sensing technique: a case of English Bazar Urban Agglomeration, West Bengal, India. Egypt J Rem Sens Space Sci 21(2):159-172. https://doi.org/10.1016/j.ejrs.2017.01.002

Soyinka O, Siu KWM (2018) Urban informality, housing insecurity, and social exclusions; concept and case study assessment for sustainable urban development. City Cult Soc 15:23-36

te Lintelo DJH, Gupte J, McGregor JA, Lakshman R, Jahan F (2018) Wellbeing and urban governance: who fails, survives or thieves in informal settlements in Bangladeshi Cities? Cities 72:391-402. https://doi.org/10.1016/j. cities.2017.10.002

Weng Q (2001) A remote sensing? GIS evaluation of urban expansion and its impact on the surface temperature in the Zhujiang Delta, China. Int J Rem Sens 22(10):1999-2014

Yuan F, Sawaya KE, Loeffelholz BC, Bauer ME (2005) Land cover classification and change analysis of the twin cities (Minnesota) metropolitan area by multitemporal Landsat remote sensing. Remote Sens Environ 98(23):317-328. https://doi.org/10.1016/j.rse.2005.08.006

\section{Submit your manuscript to a SpringerOpen ${ }^{\circ}$ journal and benefit from:}

- Convenient online submission

- Rigorous peer review

- Open access: articles freely available online

- High visibility within the field

- Retaining the copyright to your article

Submit your next manuscript at $\boldsymbol{\nabla}$ springeropen.com 